\title{
Interleukin-1 $\beta$ inhibition of insulin release in rat pancreatic islets: possible involvement of G-proteins in the signal transduction pathway
}

\author{
A. M. Rabuazzo, M. Buscema, V. Caltabiano, M. Anello, C. Degano, G. Patanè, R. Vigneri, F. Purrello \\ Institute of Internal Medicine, Metabolism and Endocrinology, University of Catania Medical School, Catania, Italy
}

Summary In vitro exposure of rat pancreatic beta cells to interleukin-1 $\beta$ (IL-1 $\beta$ ) inhibits glucose-stimulated insulin release $(2140 \pm 239$ and $323 \pm 80$ $\mathrm{pg} \cdot$ islet $^{-1} \cdot \mathrm{h}^{-1}$ at glucose levels of $16.7 \mathrm{mmol} / \mathrm{l}$ in control and IL-1 $\beta$-exposed islets, respectively, $n=7$, $p<0.001)$. Cholera toxin $(2 \mu \mathrm{g} / \mathrm{ml})$ or pertussis toxin $(0.5 \mu \mathrm{g} / \mathrm{ml})$ potentiated, as expected, glucose-induced insulin release in control islets, but, in addition, when added together with IL-1 $\beta$, were able to prevent the IL-1 $\beta$ mediated inhibition of glucose-stimulated insulin secretion $\left(2087 \pm 301\right.$ and $1662 \pm 173 \mathrm{pg} \cdot$. islet $^{-1}$. $\mathrm{h}^{-1}$, respectively, $p<0.05$ vs islets exposed to IL-1 $\beta$ alone). To investigate the mechanism by which the toxins prevent the IL- $1 \beta$ effect, we then measured nitrite levels, glucose oxidation and $\mathrm{Ca}^{2+}$ uptake. Nitrite levels in the culture medium were $4.2 \pm 1.4$ and $24.0 \pm 5 \mathrm{pmol} \cdot$ islet $^{-1} \cdot 24 \mathrm{~h}^{-1}$ in control islets and in IL-1 $\beta$-exposed islets, respectively $(n=6, p=0.05)$. In islets exposed to IL-1 $\beta$ and cholera or pertussis toxins, nitrite levels were $9.1 \pm 3$ and $12.4 \pm 6$ pmol $\cdot$ islet $^{-1} \cdot 24 \mathrm{~h}^{-1}$, respectively $(n=6, \mathrm{NS}$ vs control islets). Glucose oxidation at $16.7 \mathrm{mmol} / 1$ glucose was $31.1 \pm 2.9 \mathrm{pmol} \cdot$ islet $^{-1} \cdot 120 \mathrm{~min}^{-1}$ in control islets and $16.8 \pm 2.7 \mathrm{pmol} \cdot$ islet $^{-1} \cdot 120 \mathrm{~min}^{-1}$ in IL-1 $\beta$ treated islets $(p<0.05)$. The addition of cholera or pertussis toxins simultaneously to IL- $1 \beta$ prevented the inhibition of glucose oxidation at $16.7 \mathrm{mmol} / 1$ glucose $\left(32.9 \pm 3.8\right.$ and $31.7 \pm 3.3 \mathrm{pmol}^{- \text {islet }^{-1}}$. $120 \mathrm{~min}^{-1}$ in the presence of cholera or pertussis toxins, respectively). Glucose-stimulated ${ }^{45} \mathrm{Ca}^{2+}$ uptake was also significantly inhibited in IL-1 $\beta$-treated islets when compared to control islets (7.1 \pm 0.9 and $16.8 \pm 3.2 \mathrm{pmol} \cdot$ islet $^{-1} \cdot 20 \mathrm{~min}^{-1}$, respectively, $p<0.05)$. This inhibition was prevented by the presence of cholera or pertussis toxins $(14.0 \pm 3.8$ and $11.2 \pm 2.7 \mathrm{pmol} \cdot$ islet $^{-1} \cdot 20 \mathrm{~min}^{-1}$, respectively). In conclusion, our data show that cholera and, to a lesser extent, pertussis toxins are able to partially prevent the IL-1 $\beta$-induced increase in nitrite levels and block the inhibitory effects of IL-1 $\beta$ on different steps leading to glucose-induced insulin secretion. These findings support the possibility that in pancreatic beta cells, G-proteins may be involved or interfere with the cytokine signal transduction. [Diabetologia (1995) 38: 779-784]

Key words Interleukin-1 $\beta$, pertussis toxin, cholera toxin, pancreatic islets, insulin secretion, G-proteins, nitric oxide.
Received: 20 October 1994 and in revised form: 5 January 1995

Corresponding author: Dr. F. Purrello, Cattedra di Endocrinologia, Ospedale Garibaldi. Piazza S. Maria di Gesù, I-95123 Catania, Italy

Abbreviations: IL-1 $\beta$, Interleukin $1 \beta$; CT, cholera toxin; PT, pertussis toxin; NO, nitric oxide; FCS, fetal calf serum; KRHB, Krebs-Ringer Hepes buffer.
Interleukin-1 $\beta$ (IL-1 $\beta$ ) is believed to play a role in the process leading to beta-cell dysfunction [1-3]. Several in vitro studies have shown that chronic exposure of rat pancreatic islets and purified beta cells to IL-1 $\beta$ inhibits glucose-induced insulin release [4-10]. The exact biochemical mechanism whereby IL- $1 \beta$ affects insulin secretion, however, is still under debate. Recent data indicate that IL-1 $\beta$ activates the inducible form of nitric oxide synthase (iNOS), with the subsequent accumulation of nitric oxide (NO) [11-14]. 
The increased NO levels are likely to play a major role in rat islets and purified beta cells in mediating the IL-1 $\beta$-induced inhibition of insulin secretion and glucose oxidation, since these effects are prevented by inhibitors of NO synthase [15]. Moreover, a complete recovery of insulin secretion is observed $8 \mathrm{~h}$ after inhibition of NO synthase [16].

IL-1 $\beta$, as well as several hormones and secretagogues, exerts its biological effects on pancreatic islets by binding to a specific IL-receptor [17-20]. IL-1 $\beta$ receptors have been identified in normal rat pancreatic beta cells [21], and in the insulinoma cells RIN-m5F and HIT $[22,23]$. In a variety of cell types, including fibroblasts and T- and B-lymphocytes, the biological effects of IL-1 $\beta$ are pertussis toxin sensitive, suggesting the involvement of a Gi-like protein in IL- $1 \beta$ signalling [24-26]. G-proteins seem to play an important role as modulators of insulin secretion [27]. They link the hormone binding surface receptor to its effector system such as adenylate cyclase, phospholipases and ion channels located in the intracellular surface of the plasma membrane [28, 29]. Little is known about the intracellular signalling mechanism for the IL-1 $1 \beta / I L-1 \beta$ receptor complex in pancreatic beta cells and the involvement of G-proteins in IL$1 \beta$ effects on these cells has never been demonstrated.

In the present study we investigated whether Gproteins might be involved in the inhibitory effects of IL-1 $\beta$ on beta-cell function. For this purpose, rat pancreatic islets were pre-exposed to IL- $1 \beta$ alone or in combination with cholera (CT) or pertussis (PT) toxins, two agents commonly used for studying the G-protein function. In these cells nitrite levels (as an indicator of NO production) and glucose-induced insulin secretion were measured, as well as two important steps in the cascade of intracellular events leading to glucose-induced insulin release: glucose oxidation and $\mathrm{Ca}^{2+}$ uptake.

\section{Materials and methods}

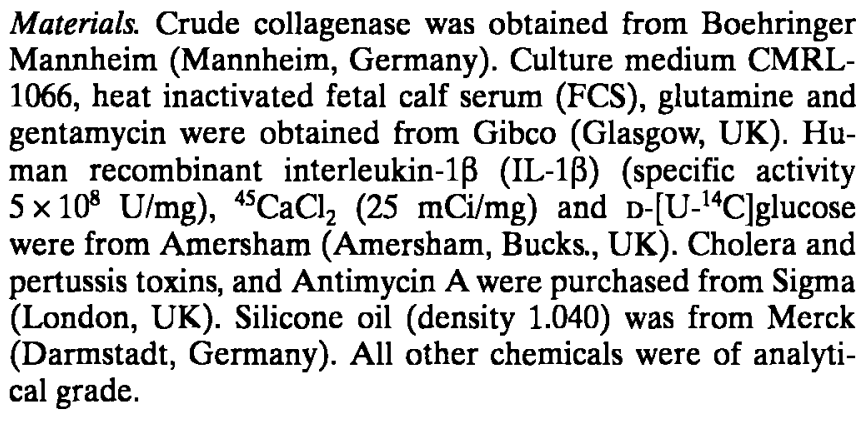

Islet preparation and culture conditions. Pancreatic islets were isolated by the collagenase method from $200-$ to $250-\mathrm{g}$ fed male Wistar rats injected i.p. with $0.2 \mathrm{ml}$ of a $0.2 \%$ pilocarpine solution $2 \mathrm{~h}$ before killing by decapitation. With this technique, $300-400$ islets were isolated from each pancreas [30].
The whole procedure was completed within $120 \mathrm{~min}$. Purified islets were cultured in CMRL-1066 medium $(5.5 \mathrm{mmol} / \mathrm{l} \mathrm{glu}$ cose) containing $10 \% \mathrm{FCS}, 2 \mathrm{mmol} / 1 \mathrm{~L}$-glutamine and gentamycin at $37^{\circ} \mathrm{C}$ in a $95 \%$ air $/ 5 \% \mathrm{CO}_{2}$ atmosphere with or without IL-1 1 \pm CT or PT for $24 \mathrm{~h}$. After this period, either insulin secretion, nitrite levels, glucose oxidation or ${ }^{45} \mathrm{Ca}^{2+}$ uptake were studied.

Insulin secretion. To study insulin secretion, triplicate groups of five purified islets were incubated in Krebs-Ringer Hepes buffer (KRHB, containing mmol/l $115 \mathrm{NaCl}, 5.4 \mathrm{KCl}, 2.38 \mathrm{CaCl}_{2}$, $0.8 \mathrm{MgSO}_{4}, 1 \mathrm{Na}_{2} \mathrm{HPO}_{4}, 10$ Hepes, $0.5 \%$ bovine serum albu$\mathrm{min}, \mathrm{pH} 7.35$ ) containing either 2.8 (basal) or $16.7 \mathrm{mmol} / \mathrm{lglu}$ cose. Insulin in the medium was measured by radioimmunoassay after $1 \mathrm{~h}$ incubation at $37^{\circ} \mathrm{C}$. Results are expressed as insulin released in the medium $\left(\mathrm{pg} \cdot\right.$ islet $\left.^{-1} \cdot \mathrm{h}^{-1}\right)$.

Nitrite determination. Nitrite, the stable end product of NO, was determined in culture medium as described by Welsh et al. [13]. Briefly, 150 islets were incubated in $0.6 \mathrm{ml}$ of culture medium for $24 \mathrm{~h}$. Triplicate samples of $90 \mu \mathrm{l}$ were then removed from the medium and added to $10 \mu \mathrm{l}$ of $0.5 \% \mathrm{~N}$-(1naphtyl)ethylendiamine dihydrochloride (NED), $5 \%$ sulphanilamide in a $25 \% \mathrm{H}_{3} \mathrm{PO}_{4}$ solution, prepared less than $12 \mathrm{~h}$ before use. The reaction was carried out at $60^{\circ} \mathrm{C}$ for $2 \mathrm{~min}$, and the absorbance at $546 \mathrm{~nm}$ was measured in a Packard spectrophotometer (Packard, Groningen, The Netherlands) against a standard curve. The detection limit was $50 \mathrm{pmol}$, and the variability of the assay was less than $5 \%$.

Glucose oxidation. Glucose oxidation was determined by measuring the formation of ${ }^{14} \mathrm{CO}_{2}$ from $\left[\mathrm{U}-{ }^{14} \mathrm{C}\right]$ glucose [31]. After $24 \mathrm{~h}$ preincubation with or without $50 \mathrm{U} / \mathrm{ml} \mathrm{IL}-1 \beta \pm$ CT or PT, groups of 15 islets were incubated in $100 \mu \mathrm{l}$ of Krebs-Ringer bicarbonate buffer $\left[(\mathrm{mmol} / \mathrm{l}) 118 \mathrm{NaCl}, 4.8 \mathrm{KCl}, 2.5 \mathrm{CaCl}_{2}, 1.2\right.$ $\left.\mathrm{MgSO}_{4}, 1.2 \mathrm{KH}_{2} \mathrm{PO}_{4}, 25 \mathrm{NaHCO}_{3}\right]$ supplemented with $10 \mathrm{mmol} / \mathrm{l}$ Hepes (pH 7.4) containing $3 \mu \mathrm{Ci} \mathrm{D}-\left[\mathrm{U}-{ }^{14} \mathrm{C}\right]$ glucose (specific activity, $270 \mathrm{mCi} / \mathrm{mmol}$ ) plus non- radioactive glucose to a final concentration of either 1.5 or $16.7 \mathrm{mmol} / \mathrm{l}$. The vials, suspended in standard 20-ml glass scintillation flasks, were gassed with air: $\mathrm{CO}_{2}$ (95:5) and capped air tight. The flasks were then shaken continuously at $37^{\circ} \mathrm{C}$ for $120 \mathrm{~min}$. The metabolism was stopped by injecting $100 \mu \mathrm{l}$ of $0.05 \mathrm{mmol} /$ 1 Antimycin A (dissolved in $70 \%$ ethanol) into the centre vial. This was immediately followed by an injection of $250 \mu \mathrm{l}$ hyamine hydroxide (New England Nuclear, Boston, Mass., USA) into the outer flasks. ${ }^{14} \mathrm{CO}_{2}$ was liberated from the incubation medium by a subsequent injection into the centre vial of $100 \mu \mathrm{l}$ of $0.4 \mathrm{mmol} / 1 \mathrm{Na}_{2} \mathrm{HPO}_{4}$ solution adjusted to $\mathrm{pH} 6.0$. After $1 \mathrm{~h}$ at room temperature (to allow the liberated ${ }^{14} \mathrm{CO}_{2}$ to be trapped by the hyamine hydroxide) $10 \mathrm{ml}$ of a scintillation fluid was added to each flask and the radioactivity determined in a liquid scintillation counter.

Calcium uptake. ${ }^{45} \mathrm{Ca}^{2+}$ uptake was measured according to the method described by Henquin and Lambert [32]. After a 24-h pre-incubation with or without $50 \mathrm{U} / \mathrm{ml} \mathrm{IL}-1 \beta \pm \mathrm{CT}$ and/or PT, groups of 15 islets were transferred into $50 \mu \mathrm{l} \mathrm{Krebs-bicarbo-}$ nate buffer modified by replacing phosphate and sulphate with equimolar amounts of chloride [33] and layered on silicone oil. The uptake period was started by adding $50 \mu \mathrm{l}$ of medium containing ${ }^{45} \mathrm{Ca}^{2+}(2.5 \mathrm{mmol} / \mathrm{l})$ and glucose (final concentration 2.8 or $16.7 \mathrm{mmol} / \mathrm{l})$. The reaction was stopped by centrifuging the islets for $2 \mathrm{~min}$ in a microfuge (Beckman Instruments, Palo Alto, Calif., USA) through the layer of silicone oil. The bottoms of the 400- $\mu$ l tubes (Beckman) were then cut and the radioactivity of the pellet counted by liquid 
Table 1. Effect of IL-1 $\beta$ with or without either CT $(2 \mu \mathrm{g} / \mathrm{ml})$ or PT $(0.5 \mu \mathrm{g} / \mathrm{ml})$ on insulin secretion $\left(\mathrm{pg} \cdot\right.$ islet $\left.^{-1} \cdot \mathrm{h}^{-1}\right)$ induced by different stimuli

\begin{tabular}{lclcccc}
\hline & \multicolumn{2}{l}{ Culture conditions } & & & \\
\cline { 2 - 7 } & Control & IL-1 $\beta$ & CT & CT + IL-1 $\beta$ & PT & PT + IL-1 $\beta$ \\
\hline Glucose $2.8 \mathrm{mmol} / 1$ & $117 \pm 32$ & $126 \pm 39$ & $198 \pm 43$ & $176 \pm 28$ & $157 \pm 28$ & $145 \pm 38$ \\
Glucose $16.7 \mathrm{mmol} / 1$ & $2140 \pm 239$ & $323 \pm 80^{\mathrm{b}}$ & $2975 \pm 271^{\mathrm{a}}$ & $2087 \pm 301$ & $3090 \pm 225^{\mathrm{a}}$ & $1662 \pm 173$ \\
\hline
\end{tabular}

Data represent mean \pm SEM of seven separate experiments.

${ }^{\mathrm{a}} p<0.05 ;{ }^{\mathrm{b}} p<0.001$ vs control islets

scintillation. Tubes without islets were run as blanks. The uptake of $\left[\mathrm{U}-{ }^{14} \mathrm{C}\right]$-sucrose was measured to correct for label in the extracellular space.

\section{Statistical analysis}

Statistical significance was assessed by Student's $t$-test for unpaired comparison.

\section{Results}

Insulin release. In control rat islets insulin release in the presence of a non-stimulatory glucose concentration $(2.8 \mathrm{mmol} / \mathrm{l})$ was $117 \pm 32 \mathrm{pg} \cdot$ islet $^{-1} \cdot \mathrm{h}^{-1}$, (mean $\pm \mathrm{SEM}, n=7$ ), and increased significantly in response to $16.7 \mathrm{mmol} / \mathrm{l}$ glucose $(2140 \pm 239, n=7)$. In islets pre-exposed for $24 \mathrm{~h}$ to $50 \mathrm{U} / \mathrm{ml} \mathrm{IL}-1 \beta$, basal insulin was not significantly affected (Table 1) but glucose-stimulated insulin release was markedly reduced (323 $\pm 80, p<0.001$ vs control islets, $n=7)$.

When increasing concentrations of either CT (dose range $0.1-5 \mu \mathrm{g} / \mathrm{ml}$ ) or PT $(0.1-2 \mu \mathrm{g} / \mathrm{ml})$ were added simultaneously to $50 \mathrm{U} / \mathrm{ml}$ IL- $1 \beta$ at the beginning of the 24-h culture period, the inhibition of glucose-stimulated insulin release was progressively prevented (Fig.1). The $50 \%$ of maximal effect was reached at a concentration of approximately $0.5 \mu \mathrm{g} /$ $\mathrm{ml}$ for CT and $0.2 \mu \mathrm{g} / \mathrm{ml}$ for PT. The maximal effect was observed at $2 \mu \mathrm{g} / \mathrm{ml} \mathrm{CT}$ and $0.5 \mu \mathrm{g} / \mathrm{ml} \mathrm{PT} \mathrm{(glu-}$ cose-stimulated insulin release $2087 \pm 301$, and $1662 \pm 173 \mathrm{pg} \cdot$ islet $^{-1} \cdot \mathrm{h}^{-1}$, respectively). In islets treated for $24 \mathrm{~h}$ with $2 \mu \mathrm{g} / \mathrm{ml} \mathrm{CT}$ or $0.5 \mu \mathrm{g} / \mathrm{ml}$ PT alone basal insulin release was unchanged, but glucose-stimulated insulin secretion was potentiated (Table 1).

To examine the possibility that the CT and PT effect on IL- $1 \beta$ inhibition of insulin release could be reversed by agents that increase cAMP levels without affecting G-proteins, we incubated groups of islets in the presence or the absence of IL-1 $\beta$ and forskolin (an agent known to increase cAMP levels by directly activating the enzyme adenyl cyclase). Unfortunate$\mathrm{ly}$, in islets incubated for $24 \mathrm{~h}$ in the presence of forskolin $(5 \mu \mathrm{mol} / \mathrm{l})$ glucose-stimulated insulin release was reduced $\left(690 \mathrm{pg} \cdot\right.$ islet $^{-1} \cdot \mathrm{h}^{-1}, n=4, p<0.01$ vs
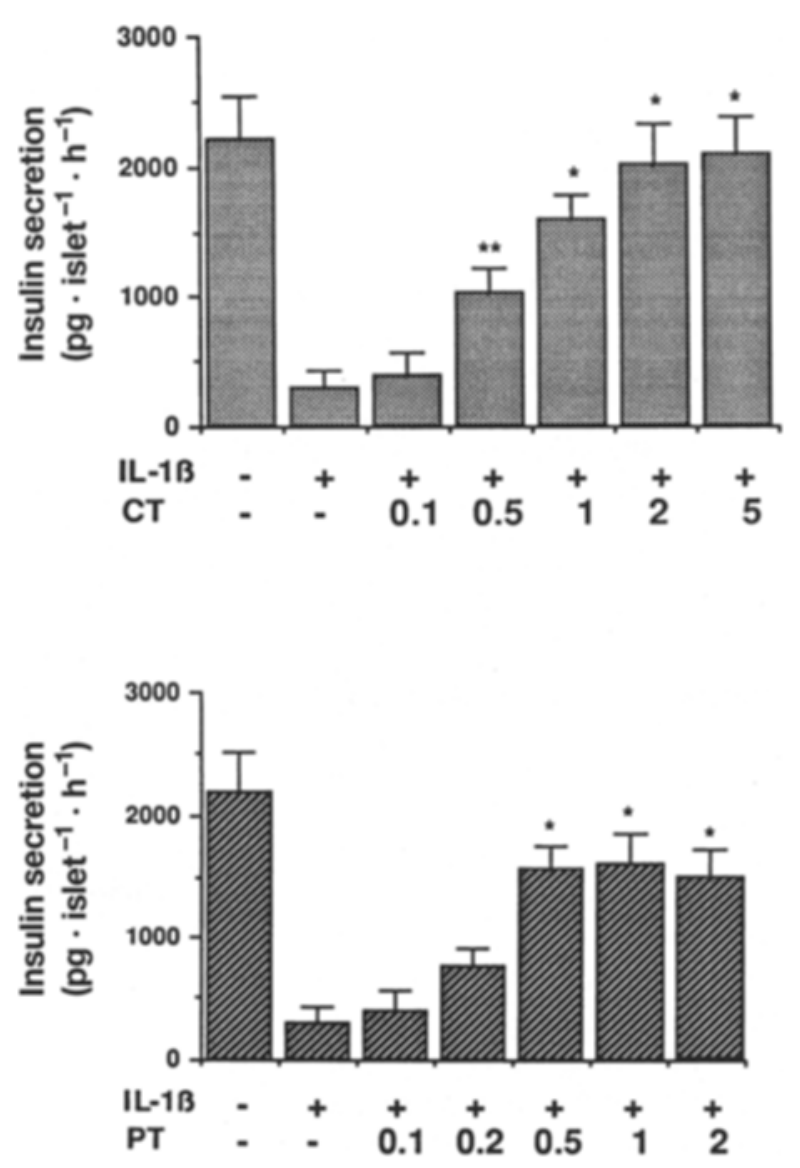

Fig. 1. Glucose-stimulated insulin release in rat pancreatic islets cultured for $24 \mathrm{~h}$ in the absence or presence of $50 \mathrm{U} / \mathrm{ml}$ IL-1 $\beta$ plus increasing concentrations of CT (upper panel) or PT (lower panel). At the end of the $24 \mathrm{~h}$ pre-incubation period, islets were washed three times and incubated for $1 \mathrm{~h}$ at $37^{\circ} \mathrm{C}$ in $\mathrm{KRHB}$ containing $16.7 \mathrm{mmol} / \mathrm{l}$ glucose. Results (mean \pm SEM of four separate experiments) are expressed as insulin released in the medium $\left(\mathrm{pg} \cdot\right.$ islet $\left.^{-1} \cdot \mathrm{h}^{-1}\right) .{ }^{* *} p<0.05$, ${ }^{*} p<0.005$ vs islets treated with IL-1 $\beta$ alone

control islets), thus making the interpretation of the results difficult. In islets exposed to IL-1 $\beta(50 \mathrm{U} / \mathrm{ml})$ and forskolin $(5 \mu \mathrm{mol} / \mathrm{l})$ glucose-stimulated insulin release was $489 \mathrm{pg} \cdot$ islet $^{-1} \cdot \mathrm{h}^{-1}(n=4)$.

Nitrite levels. Nitrite levels in the culture medium were $4.2 \pm 1.4$ and $24.0 \pm 5$ pmol $\cdot$ islet $^{-1} \cdot 24 \mathrm{~h}^{-1}$ in control islets and in IL-1 $\beta$-exposed islets, respectively $(n=6, p<0.05)$. In islets exposed to IL-1 $\beta$ and CT or 
Table 2. Effect of IL-1 $\beta$ with or without CT and/or PT on glucose oxidation (pmol $\cdot$ islet $^{-1} \cdot 120 \mathrm{~min}^{-1}$ )

\begin{tabular}{|c|c|c|c|c|c|c|}
\hline & \multicolumn{6}{|c|}{ Culture conditions } \\
\hline & Control & IL- $1 \beta$ & CT & $\mathrm{IL}-1 \beta+\mathrm{CT}$ & PT & $\mathrm{IL}-1 \beta+\mathrm{PT}$ \\
\hline \multicolumn{7}{|l|}{ Secretagogues } \\
\hline Glucose $1.5 \mathrm{mmol} / \mathrm{l}$ & $7.3 \pm 0.8$ & $9.0 \pm 1.2$ & $10.9 \pm 1.4$ & $11.3 \pm 2.1$ & $8.8 \pm 1.0$ & $8.1 \pm 1.1$ \\
\hline Glucose $16.7 \mathrm{mmol} / 1$ & $31.1 \pm 2.9$ & $16.8 \pm 2.7^{\mathrm{a}}$ & $33.4 \pm 4.0$ & $32.9 \pm 3.8$ & $32.5 \pm 3.6$ & $31.7 \pm 3.3$ \\
\hline
\end{tabular}

${ }^{a} p<0.005$ in respect to control islets

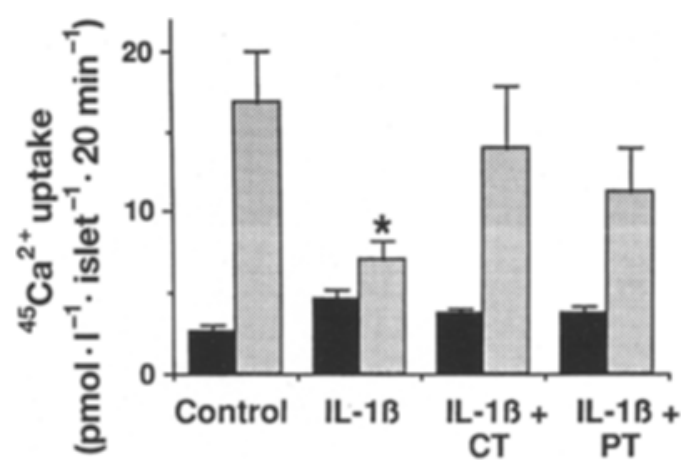

Fig. 2. Basal $(\square)$ and glucose-stimulated (央) $\mathrm{Ca}^{2+}$ uptake in rat pancreatic islets cultured for $24 \mathrm{~h}$ in the absence (control) or in the presence of $50 \mathrm{U} / \mathrm{ml} \mathrm{IL}-1 \beta$, with or without CT $(2 \mu \mathrm{g} /$ $\mathrm{ml})$ or PT $(0.5 \mu \mathrm{g} / \mathrm{ml})$. At the end of the $24-\mathrm{h}$ pre-incubation period, islets were washed three times and incubated for $20 \mathrm{~min}$ at $37^{\circ} \mathrm{C}$ in buffer containing either 2.8 or $16.7 \mathrm{mmol} / \mathrm{l}$ glucose. $\mathrm{Ca}^{2+}$ uptake is expressed as pmol $\cdot \mathrm{l}^{-1} \cdot$ islet $^{-1}$ . $20 \mathrm{~min}^{-1}$. Data represent mean \pm SEM of six separate experiments. ${ }^{*} p<0.005$ vs control islets

PT, nitrite levels were $9.1 \pm 3$ and $12.4 \pm 6$ pmol · islet $^{-1} \cdot 24 \mathrm{~h}^{-1}$, respectively ( $n=6$, NS vs control islets). In islets exposed to CT or PT alone, in the absence of IL-1 $\beta$, nitrite levels were not different from control islets $(4.6 \pm 2.0$ and $4.8 \pm 1.9$, respectively).

Glucose oxidation. In control islets cultured in the absence of IL-1 $\beta$, glucose oxidation increased from $7.3 \pm 0.8 \mathrm{pmol} \cdot$ islet $^{-1} \cdot 120 \mathrm{~min}^{-1}$ at $1.5 \mathrm{mmol} / \mathrm{l}$ glucose to $31.1 \pm 2.9 \mathrm{pmol} \cdot$ islet $^{-1} \cdot 120 \mathrm{~min}^{-1}$ at $16.7 \mathrm{mmol} / \mathrm{l}$ of glucose. In islets cultured for $24 \mathrm{~h}$ with $50 \mathrm{U} / \mathrm{ml} \mathrm{IL}-1 \beta$, glucose oxidation at $1.5 \mathrm{mmol} / \mathrm{l}$ glucose was similar to the control value, but the response to $16.7 \mathrm{mmol} / \mathrm{l}$ glucose was significantly impaired (Table 2).

When islets were cultured in the presence of both IL-1 $\beta$ and either CT or PT, the basal oxidation rate (at glucose $1.5 \mathrm{mmol} / \mathrm{l}$ ) was slightly higher than that observed in control islets, although the difference was not significant (Table 2). Moreover, in these islets glucose oxidation in the presence of $16.7 \mathrm{mmol} / \mathrm{l}$ glucose was similar to control islets (Table 2). Neither toxin had a significant effect on glucose oxidation in the absence of IL-1B (Table 2).
$\mathrm{Ca}^{2+}$ uptake. In control islets, ${ }^{45} \mathrm{Ca}^{2+}$ uptake was $2.6 \pm 0.4 \mathrm{pmol} \cdot$ islet $^{-1} \cdot 20 \mathrm{~min}^{-1}$ (mean $\left.\pm \mathrm{SEM}, n=6\right)$ under basal conditions (i.e. in the presence of $2.8 \mathrm{mmol} / \mathrm{l}$ glucose) and increased to $16.8 \pm$ $3.2 \mathrm{pmol} \cdot$ islet $^{-1} \cdot 20 \mathrm{~min}^{-1}$ in the presence of $16.7 \mathrm{mmol} / 1$ glucose. In pancreatic islets pre-exposed to $50 \mathrm{U} / \mathrm{ml}$ IL-1 $\beta$, calcium uptake under basal conditions was higher than in control islets $(4.4 \pm 0.5$ pmol $\cdot$ islet $\left.^{-1} \cdot 20 \mathrm{~min}^{-1}, p<0.05\right)$, but only slightly increased after $16.7 \mathrm{mmol} / \mathrm{l}$ glucose stimulation $\left(7.1 \pm 0.9 \mathrm{pmol} \cdot\right.$ islet $^{-1} \cdot 20 \mathrm{~min}^{-1}, p<0.005$ vs control islets) (Fig.2). When $2 \mu \mathrm{g}$ CT or $0.5 \mu \mathrm{g}$ PT were added simultaneously to IL-1 $\beta$, both basal and glucoseinduced calcium uptake were similar to control islets $\left(3.7 \pm 0.3\right.$ and $3.7 \pm 0.4 \mathrm{pmol} \cdot$ islet $^{-1} \cdot 20 \mathrm{~min}^{-1}$, basal values, and $14.0 \pm 3.8$ and $11.2 \pm 2.7 \mathrm{pmol} \cdot$ islet $^{-1} \cdot 20 \mathrm{~min}^{-1}$, glucose-stimulated values in the presence of CT or PT, respectively, Fig.2). Neither CT nor PT alone modified basal or glucose-stimulated ${ }^{45} \mathrm{Ca}^{2+}$ uptake (data not shown).

\section{Discussion}

The present study confirms that IL- $1 \beta$ is able to increase NO production, as measured by the nitrite levels, and to inhibit glucose oxidation, glucose-stimulated $\mathrm{Ca}^{2+}$ uptake and the glucose-induced insulin secretion in isolated rat pancreatic islets. Our data also demonstrate that the presence of CT or PT together with IL-1 $\beta$ prevents all the inhibitory effects of the cytokine, therefore suggesting that they are mediated by CT and PT substrates. Since both toxins prevent, at least partially, the IL-1 $\beta$-induced increase in nitrite levels, they probably interfere with IL-1 $\beta$ signal transduction, and are not mainly acting by stimulating insulin secretion.

The free radical NO has been proposed to play a major role in mediating the IL- $1 \beta$-induced inhibition of insulin secretion in rat islets [11-14]. NO is formed by a cytokine-inducible NO synthase, and inhibits key enzymes involved in glucose metabolism and energy production [13]. As a consequence, signals arising from it and coupling glucose metabolism and insulin secretion are impaired. In the cascade of intracellular events leading to insulin secretion, glucose metabolism is an early step that (by increasing the ATP content) leads to membrane depolarisation 
and subsequent $\mathrm{Ca}^{2+}$ influx, the suggested trigger for insulin release. The impaired $\mathrm{Ca}^{2+}$ uptake and insulin release observed after islet exposure to IL-1 $\beta$ may, therefore, be secondary to the cytokine inhibitory effect of NO on glucose metabolism. In our experiments, CT and PT, by partially preventing the increase in NO levels, may hinder the inhibition of glucose oxidation and restore the signalling pathway that leads to glucose-induced $\mathrm{Ca}^{2+}$ uptake and, eventually, insulin release. This possibility is supported by the observation that in IL- $1 \beta$-exposed islets both $\mathrm{Ca}^{2+}$ uptake and insulin release are normal in response to glyburide [34]. Therefore, since in IL-1 $\beta$ exposed islets $\mathrm{Ca}^{2+}$ uptake and insulin release in response to a stimulation different from glucose are normal, it is likely that the IL- $1 \beta$ inhibitory effect at the level of glucose metabolism is the primary dysfunction caused by the cytokine in pancreatic beta cells.

Our study is unable to precisely identify the effector system involved in the transmission signal of the IL- $1 \beta / \mathrm{IL}-1 \beta$ receptor complex. The G-proteins seem to play an important role as modulators of insulin secretion $[27,35,36]$. They specifically mediate the inhibitory effects of several hormones such as somatostatin, galanine and epinephrine. These effects are prevented by beta-cell treatment with PT [37-40]. CT and PT have been reported to specifically and irreversibly activate different $\mathrm{G}$-proteins $\left(\mathrm{Gi}_{1-3}, \mathrm{Go}_{1,2}\right)$ $[35,41]$. The observations that both CT and PT are able to prevent the IL-1 $\beta$-induced effects and that CT is more effective than PT suggest that multiple G-proteins are involved in the signal transmission of the IL- $1 \beta$ receptor, and that the activation of CT and PT substrate pathway may overcome the block. However, it has been previously reported that the G-protein bound to the IL- $1 \beta$ receptor may be a common substrate for both CT and PT [25], and that CT can ribosylate PT-sensitive substrates [41]. As an alternate possibility G-proteins may not be directly involved in IL-1 $\beta$ signal transmission, but the CT and PT effects may be mediated by an increase in cAMP levels. We tried to examine this possibility by incubating islets with forskolin (an agent known to increase cAMP levels by directly activating the enzyme adenyl cyclase), in the presence or absence of IL-1 $\beta$. These results, however, are difficult to interpret because in forskolin-exposed islets glucose-induced insulin release was decreased. Similar results have been previously obtained [42], and may be due to islet desensitization [43].

Previous studies were unable to demonstrate an effect of PT on IL-1 $\beta$ inhibition of insulin secretion in fetal [44], adult rat islets [45] or RIN cells [46]. However, the experimental design was quite different. In particular, in the study by Sjöholm [44] the fetal islets were treated for $24 \mathrm{~h}$ with PT prior to the addition of IL-1 $\beta$; in the study by Eizirik et al. [45], islets were exposed for $1 \mathrm{~h}$ to IL-1 $\beta$ and studied $12 \mathrm{~h}$ later. Our study shows that the contemporary presence of CT and PT together with IL-1 $\beta$ during the 24-h culture period is necessary to prevent the inhibitory effects of the cytokine. The different results in RIN cells [46] may be due to the large difference in glucose metabolism between normal and tumoural cells. This difference may be of critical significance, mitochondrial glucose metabolism being among the proposed targets of IL-1 $\beta$ action in pancreatic beta cells.

In conclusion, our data confirm that IL-1 $\beta$ has an inhibitory effect on glucose-induced insulin release in pancreatic beta cells and show that this effect may be prevented by the presence of CT or PT, suggesting the involvement of a G-protein-dependent pathway. The effector system involved, however, remains unknown.

\section{References}

1. Dinarello CA (1984) Interleukin 1 and the pathogenesis of the acute-phase response. N Engl J Med 311: 1413-1418

2. Mandrup-Poulsen T, Zumsteg U, Reimers J et al. (1993) Involvement of interleukin-1 and interleukin-1 antagonist in pancreatic beta-cell destruction in insulin-dependent diabetes mellitus. Cytokine 5: 185-191

3. McDaniel ML, Hughes JH, Wolf BA, Easom RA, Turk JW (1988) Descriptive and mechanistic considerations of interleukin 1 and insulin secretion. Diabetes 37: 1311-1315

4. Zawalich WS, Diaz VA (1986) Interleukin-1 inhibits insulin secretion from isolated perifused rat islets. Diabetes 35: 1119-1123

5. Sandler S, Andersson A, Hellerström C (1987) Inhibitory effects of interleukin 1 on insulin secretion, insulin biosynthesis and oxidative metabolism of isolated rat pancreatic islets. Endocrinology 121: 1424-1431

6. Comens PG, Wolf PA, Unanue ER, Lacy PE, McDaniel ML (1987) Interleukin 1 is a potent modulator of insulin secretion from isolated rat islets of Langerhans. Diabetes 36: 963-970

7. Rabinovitch A, Pukel C, Baquerizo H (1988) Interleukin-1 inhibits glucose- modulated insulin and glucagon secretion in rat islet monolayer cultures. Endocrinology 122: 23932397

8. Eizirik DL, Strandell E, Bendtzen K, Sandler S (1988) Functional characteristics of rat pancreatic islets maintained in culture following exposure to human interleukin 1. Diabetes 37: 916-919

9. Purrello F, Buscema M (1993) Effects of interleukin $1 \beta$ on insulin secretion by pancreatic beta cells. Diab Nutr Metab 6: 295-304

10. Ling Z, In't Veld P, Pipeleers DG (1993) Interaction of interleukin-1 with islet $\beta$-cells. Distinction between indirect, aspecific cytotoxity and direct, specific functional suppression. Diabetes 42: 56-65

11. Southern C, Schulster D, Green IC (1990) Inhibition of insulin secretion by interleukin- $1 \beta$ and tumour necrosis factor-a via an L-arginine dependent nitric oxide generating mechanism. FEBS Lett 276: 42-44

12. Kroncke KD, Kolb-Bachofen V, Berschick B, Burkart V, Kolb H (1991) Activated macrophages kill pancreatic syngenic islet cells via arginine- dependent nitric oxide generation. Biochem Biophys Res Commun 175: 752-758 
13. Welsh N, Eizirik DL, Bendtzen K, Sandler S (1991) Interleukin-1 $\beta$ induced nitric oxide production in isolated rat pancreatic islets requires gene transcription and may lead to inhibition of the Krebs Cycle enzyme aconitase. Endocrinology 129: 3167-3173

14. McDaniel ML, Corbett JA (1992) Does nitric oxide mediate autoimmune destruction of B-cells? Possible therapeutic interventions in IDDM. Diabetes 41: 897-903

15. Corbett JA, Wang JL, Hughes JH et al. (1992) Nitric oxide and cyclic GMP formation induced by interleukin $1 \beta$ in islets of Langerhans. Biochem J 287: 229-235

16. Corbett JA, McDaniel ML (1994) Reversibility of interleukin-1 $\beta$-induced islet destruction and dysfunction by the inhibition of nitric oxide synthase. Biochem J 299: 719-724

17. Dower SK, Urdal DL (1987) The interleukin-1 receptor. Immunology Today 8: 46-51

18. Dower SK, Kronheim SR, Hopp TP et al. (1986) The cell surface receptors for interleukin-1 $\alpha$ and interleukin-1 $\beta$ are identical. Nature 324: 266-268

19. Urdal DL, Call SM, Jackson JL, Dower SK (1988) Affinity purification and chemical analysis of the interleukin-1 receptor. J Biol Chem 263: 2870-2877

20. Dinarello CA, Clark BD, Puren AS, Savage N, Rosoff PM (1989) The interleukin 1 receptor. Immunology Today 10: 49-51

21. Eizirik DL, Tracey DE, Bendtzen K, Sandler S (1992) Role of receptor binding and gene transcription for both the stimulatory and inhibitory effects of interleukin-1 in pancreatic beta-cells. Autoimmunity 12: 127-133

22. Eizirik DL, Tracey DE, Bendtzen K, Sandler S (1991) An interleukin-1 receptor antagonist protein protects insulinproducing B-cells against suppressive effects of interleukin-13. Diabetologia 34: 445-448

23. Hammonds P, Beggs M, Beresford G, Espinal J, Clarke J, Mertz RJ (1990) Insulin-secreting $\beta$-cells possess specific receptors for interleukin-1 $\beta$. FEBS Lett 261: 97-100

24. Mizel SB (1989) The interleukins. FASEB J 3: 2379-2388

25. Chedid M, Shirakawa F, Naylor P, Mizel SB (1989) Signal transduction pathway for IL-1. Involvement of a pertussis toxin-sensitive GTP-binding protein in the activation of adenylate cyclase. J Immunol 142: 4301- 4306

26. Mizel SB (1990) Cyclic AMP and interleukin 1 signal transduction. Immunology Today 11: 390-391

27. Robertson RP, Seaquist ER, Walseth TF (1991) G-proteins and modulation of insulin secretion. Diabetes 40: 1-6

28. Freissmuth M, Casey PJ, Gilman AG (1989) G-proteins control diverse pathways of transmembrane signalling. FASEB J 3: 2125-2131

29. Bimbaumer L (1990) $G$ proteins in signal transduction. Annu Rev Pharmacol Toxicol 30: 675-705

30. Purrello F, Vetri M, Gatta C, Gullo D Vigneri R (1989) Effects of high glucose on insulin secretion by isolated rat islets and purified B-cells and possible role of glycosylation. Diabetes 38: 1417-1422

31. Svensson C, Hellerström (1991) Long-term effects of a high glucose concentration in vitro on the oxidative metabolism and insulin production of isolated rat pancreatic islets. Metabolism 40: 513-518

32. Henquin JC, Lambert AE (1975) Cobalt inhibition of insulin secretion and calcium uptake by isolated rat islets. Am J Physiol 228: 1669-1677
33. Flatt PR, Berggren PO, Gylfe E, Hellman BO (1980) Calcium and pancreatic B-cell function. Demonstration of lanthanid-induced inhibition of insulin secretion independent of modifications in transmembrane $\mathrm{Ca}^{2+}$ fluxes. Endocrinology 107: 1007-1013

34. Buscema M, Rabuazzo A M, Vinci C, Caltabiano V, Vigneri R, Purrello F (1993) Different effects of glucose and glyburide on insulin secretion in rat pancreatic islets preexposed to interleukin-1 $\beta$. Possible involvement of $\mathrm{K}^{+}$ and $\mathrm{Ca}^{2+}$ channels. Diabetologia 36: 791-796

35. Seaquist ER, Robertson Neal A, Shoeger KD, Walseth TF, Robertson P (1992) G proteins and hormonal inhibition of insulin secretion from HIT-T15 cells and isolated rat islets. Diabetes 41: 1390-1399

36. Baffy G, Yang L, Wolf BA, Williamson JR (1993) G protein specificity in signalling pathways that mobilize calcium in insulin-secreting $\beta$-TC3 cells. Diabetes 42: 1878-1882

37. Hsu WH, Xiang H, Rajan AS, Kunze DL, Boyd III AE (1991) Somatostatin inhibits insulin secretion by a G-protein-mediated decrease in $\mathrm{Ca}^{2+}$ entry through voltage-dependent $\mathrm{Ca}^{2+}$ channels in the beta cell. J Biol Chem 266: 837-843

38. Nilsson T, Arkhammar P, Rorsman P, Berggren PO (1989) Suppression of insulin release by galanin and somatostatin is mediated by a $\mathrm{G}$-protein. An effect involving repolarization and reduction in cytoplasmic free $\mathrm{Ca}^{2+}$ concentration. J Biol Chem 264: 973-980

39. Schmidt A, Hescheler J, Offermanns S et al. (1991) Involvement of pertussis toxin-sensitive G-proteins in the hormonal inhibition of dihydropyridine-sensitive $\mathrm{Ca}^{2+}$ currents in an insulin-secreting cell line (RINm5F). J Biol Chem 266: 18025-18033

40. Cormont M, Le Marchand-Brustel Y, Van Obberghen E, Spiegel AM, Sharp GWG (1991) Identification of G-protein alpha-subunits in RINm5F cells and their selective interaction with galanin receptor. Diabetes 40: 1170-1176

41. Gillison SL, Sharp GW (1994) ADP ribosylation by cholera toxin identifies three G-proteins that are activated by the galanin receptor. Diabetes 43: 24- 32

42. Green IC, Delaney CA, Cunningham JM, Karmiris V, Southern C (1993) Interleukin-1 $\beta$ effects on cyclic GMP and cyclic AMP in cultured rat islets of Langerhans argine-dependence and relationship to insulin secretion. Diabetologia 36: 9-16

43. Grodsky G, Bolaffi JL (1992) Desensitization of the insulin-secreting beta cell. J Cell Biochem 48: 3-11

44. Sjöholm A (1991) Inhibition of fetal rat pancreatic $\beta$-cell replication by interleukin $1 \beta$ in vitro is not mediated through pertussis toxic-sensitive G- protein, a decrease in cyclic AMP, or protease activation. FEBS Lett 289: 249-252

45. Eizirik DL, Tracey DE, Bendtzen K, Sandler S (1992) Role of receptor binding and gene transcription for both the stimulatory and inhibitory effects of interleukin-1 in pancreatic beta-cells. Autoimmunity 12: 127-133

46. Sjöholm A (1991) Cytokines inhibit proliferation and insulin secretion by clonal rat insulinoma cells (RINmSF) nonsynergistically and in a pertussis- insensitive manner. Immunol Lett 30: 81-86 